\title{
MULTIBUBBLES IN BORSA ISTANBUL RETAIL STOCKS DURING COVID19 PANDEMIC
}

\author{
DOI: 10.17261/Pressacademia.2021.1519 \\ PAP- V.14-2021(45)-p.158-159
}

Hakan Mentes ${ }^{1}$, Ayben Koy²,

${ }^{1}$ Istanbul Commerce University, Institute of Finance, Istanbul, Turkey.

hakanmentees@gmail.com ,ORCID: 0000-0003-4463-4278

${ }^{2}$ Istanbul Commerce University, Faculty of Business, Finance and Banking, Sutluce Campus, Istanbul, Turkey. akoy@ticaret.edu.tr, ORCID: 0000-0002-2506-6634

\section{To cite this document}

Mentes, H., Koy, A., (2021). Multıbubbles in Borsa Istanbul retail stocks during Covid-19 pandemic (2021). PressAcademia Procedia (PAP), 14, 158-159.

Permanent link to this document: http://doi.org/10.17261/Pressacademia.2021.1519

Copyright: Published by PressAcademia and limited licensed re-use rights only.

\begin{abstract}
Purpose- Asset bubbles, which can be explained as the separation of financial asset prices from the random walk process, can be shown up in different financial markets. Tirole (1985) counts the three actors that cause bubbles: durability, scarcity and common beliefs. These common beliefs can also be associated with the behavioral finance approach. In the behavioral approach, bubbles are explained by herding behavior. Investors making similar decisions in the same directions do not mean that there is always a herding behavior. In the efficient markets, the information is available to all investors that they make transactions in the same direction by evaluating the information same. While the investors are rational, they make similar investment decisions. Buying or selling the same securities without a specific reason is defined as herding behavior. In this study, the existence of price bubbles in the stocks of companies traded in the BIST100 retail index related to the Covid-19 epidemic period is investigated.

Methodology- The study employs Sup Augmented Dickey Fuller (SADF) and Generalized Sup Augmented Dickey Fuller (GSADF) tests to investigate the presence of bubbles or date the bubbles. The period of the study is from January 2016 to September 2021.

Findings- The results of the SADF test identify price bubbles in all stocks except one, the GSADF test gives results indicating that there are bubbles in all stocks.

Conclusion- During the covid19 pandemic, both the sectoral reasons specific to the pandemic and the participation of many new investors in the financial markets caused high price movements in stocks and especially in the retail sector. This study explores asset bubbles during the covid19 pandemic. The results prove that there are single and multiple bubbles in the stocks in the BIST retail index.
\end{abstract}

Keywords: Bubble, covid19, retail, stock market

JEL Codes: G12, G14

\section{REFERENCES}

Akkaya, M. (2018). BORSA iSTANBUL HISSE SENEDi GETiRiLERINDE BALON. C.Ü. İktisadi ve İdari Bilimler Dergisi, 19(1), 188-200

Altay, E. (2008). Sermaye piyasasında sürü davranışı: IMKB'de piyasa yönünde sürü davranışının analizi. BDDK Bankacılık ve Finansal Piyasalar Dergisi, 2(1), 27-58

Baker, S., Bloom, N., Davis, S., \& Terry, S. (2020). COVID Kaynaklı Ekonomik Belirsizlik. Natıonal Bureau of Economıc Research, 26983.

Fama, E. (1965). Borsa Fiyatlarında Rastgele Yürüyüşler. Finansal Analistler Dergisi, 21(5), 55-59.

Fama, E. (1970). Etkin Sermaye Piyasaları: Teori ve Ampirik Çalışmanın Gözden Geçirilmesi. Finans Dergisi, $383-417$.

Haroon, O., \& Rizvi , S. (2020). COVID-19: Medya kapsamı ve finansal piyasalar davranışı-Sektörel bir soruşturma. Davranışsal ve Deneysel Finans Dergisi, 27.

Kıyılar, M., \& Akkaya, M. (2016). Davranışşsal Finans. Türkiye: Literatür Yayıncılık.

Koy, A. (2018). Gelişmekte Olan Pay Piyasalarında . Finans Politik \& Ekonomik Yorumlar , 55(637), 95-109. 
Koy, A. (2018). Testing Multi Bubbles for Commodity Derivative Markets: A Study on MCX. Business and Economics Research Journal, 9(2), 291-299.

Şenol, Z. (2020). COVID-19 KRizi VE FiNANSAL PiYASALAR. N. Toğuç içinde, Para ve Finans (s. 75-124). Sivas: İksad Yayınevi.

Tirole, J. (1985). Asset Bubbles and Overlapping Generations. Econometrica,, 53(6), 1499-1528. 